\title{
Stable Isotopes from Diatom Silica
}

\author{
Melanie J. Leng \\ NERC Isotope Geosciences Laboratory \\ British Geological Survey \\ Keyworth \\ Nottingham \\ NG12 5GG \\ $U K$ \\ \& \\ School of Geography \\ University of Nottingham \\ Nottingham \\ NG7 2RD \\ $U K$ \\ mil@bgs.ac.uk
}

\section{George E. A. Swann}

NERC Isotope Geosciences Laboratory

British Geological Survey

Keyworth

Nottingham

NG12 5GG

$U K$

\section{gean@bgs.ac.uk}

\section{Introduction}

Diatom silica is a form of biogenic opal $\left(\mathrm{SiO}_{2} \cdot \mathrm{nH}_{2} \mathrm{O}\right.$, Figure 1) containing oxygen, silicon, carbon and nitrogen isotopes that can be used in lacustrine and marine paleoenvironmental studies. Since diatoms bloom following a seasonal pattern defined partly by the variability of climate, nutrient supply, mixing regimes, and in high latitudes the period of ice cover, the isotope signature acquired by diatoms will be skewed toward their major growing season specific to the lake or oceanic region under consideration. 
The isotope ratio (e.g. ${ }^{18} \mathrm{O} /{ }^{16} \mathrm{O},{ }^{30} \mathrm{Si} /{ }^{28} \mathrm{Si},{ }^{13} \mathrm{C} /{ }^{12} \mathrm{C},{ }^{15} \mathrm{~N} /{ }^{14} \mathrm{~N}$ ) of diatom silica are expressed on the deltascale $(\delta)$ in terms of per mille (or per mille) (\%o):

$$
\delta=\left[\left(\mathrm{R}_{\text {sample }} / \mathrm{R}_{\text {reference }}\right)-1\right] \cdot 1000 \%
$$

Where $\mathrm{R}$ is the particular isotope ratio (e.g. ${ }^{18} \mathrm{O} /{ }^{16} \mathrm{O},{ }^{30} \mathrm{Si} /{ }^{28} \mathrm{Si}$ ), and 'reference' means the appropriate universally accepted reference material. The ' $\delta$ ' for each element takes its name from the heavy isotope, thus $\delta^{18} \mathrm{O}, \delta^{30} \mathrm{Si}, \delta^{13} \mathrm{C}, \delta^{15} \mathrm{~N}$. For diatom oxygen the reference is VSMOW (Vienna Standard Mean Ocean Water) calibrated through the quartz NBS28, for silicon it is referenced and measured alongside NBS28, for carbon the reference is VPDB (Vienna PeeDee Belemnite) calibrated against NBS19 and NBS22, and for nitrogen it is atmospheric nitrogen, commonly shortened to AIR. There are no universally accepted standard materials to analyse alongside diatoms although most laboratories use their own standard diatomites as well as NBS quartz and low $\% \mathrm{C}$ and $\% \mathrm{~N}$ organic materials.

\section{Environmental signals from diatom isotopes}

\subsection{Oxygen isotopes}

The oxygen isotope composition of diatoms $\left(\delta^{18} \mathrm{O}_{\text {diatom }}\right)$ is primarily a function of changes in ambient water temperature and the isotopic composition of water $\left(\delta^{18} \mathrm{O}_{\text {water }}\right)$ surrounding the frustule. The temperature dependence of oxygen isotope fractionation between diatom silica and water has not been rigorously derived, although the relationship has been estimated from analyses of diatoms from marine and freshwater sediments, coupled with estimates of the temperatures and isotope compositions of coexisting waters during silica formation (e.g. Labeyrie, 1974). The data from these calibration studies are limited, and are mainly based on bulk samples not individual diatom species (although Brandriss et al. (1998) provides a notable exception). Historical estimates of the average temperature dependence based on these samples ranges from -0.3 to $-0.5 \% /{ }^{\circ} \mathrm{C}$ (Juillet-Leclerc and Labeyrie, 1987; Shemesh et al., 1992). More recently, however, controlled experiments on lacustrine diatoms (Brandriss et al., 1998; Moschen et al., 2006) have shown that the true diatom-temperature coefficient is likely to be closer to $-0.2 \%{ }^{\circ} \mathrm{C}$.

Since diatoms are physically difficult to separate into single species samples due to their small size $(2-200 \mu \mathrm{m})$, bulk samples comprised of different taxa are normally analysed for diatom isotopes.

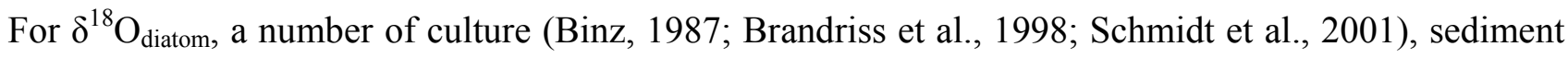
trap (Moschen et al., 2005) and down-core studies (Sancetta et al., 1985; Juillet-Leclerc and Labeyrie, 
1987; Shemesh et al., 1995; Schiff et al., 2009) in marine and lacustrine systems have failed to find evidence of any isotope/disequilibrium vital effect either within or between individual diatom taxa. Whilst Brandriss et al. (1998) documented a 0.6\% offset between two taxa and Shemesh et al. (1995) found a $0.2 \%$ offset between different size fractions of diatoms, these offsets are within the range of reproducibility routinely achieved when analyzing $\delta^{18} \mathrm{O}_{\text {diatom }}$ (Section 4.1 ). This is in contrast to biogenic carbonates in which $\delta^{18} \mathrm{O}$ measurements, offset from those predicted purely by thermodynamics, can occur in response to variations in kinetic or metabolic processes, e.g. changes in growth rates, nutrient availability or rates of calcification/silicification (Duplessy et al., 1970; Wefer and Berger, 1991; Spero and Lea, 1993, 1996; Spero et al., 1997; Bemis et al., 1998). Recent results from the North West Pacific Ocean on sediment core material, however, has documented isotope offsets of up to $3.5 \%$ between two size fractions of diatoms (Swann et al., 2007; 2008). Whilst the mechanisms behind this remains unresolved, these offsets may be related to suggestions that changes in growth rates may influence oxygen isotope fractionation in diatoms (Schmidt et al., 2001).

The diatom frustule is comprised of two layers: a tetrahedrally bonded silica (-Si-O-Si) layer and an outer hydrous (-Si-OH) layer. Whereas the -Si-O-Si layer contains oxygen incorporated into the frustule during silicification, the oxygen in the -Si-OH layer is able to freely exchange with any water the diatom comes into contact with and must be removed prior to isotope analysis (see Section 4.1). A key assumption for $\delta^{18} \mathrm{O}_{\text {diatom }}$ is that no oxygen isotope exchange occurs between the Si-O-Si layer and the-Si-OH layer during or after sedimentation (Julliet, 1980a, b). Schmidt et al. (1997), who analyzed the oxygen isotope composition of live diatom frustules collected from the oceans, however, found no regular correlation between temperature and oxygen isotope fractionation. Marine and lacustrine diatoms have also been shown to have significantly lower, $2 \%$ to $10 \%, \delta^{18} \mathrm{O}_{\text {diatom }}$ fractionation factors that those obtained with diatoms cultured in a laboratory. (Schmidt et al., 1997; 2001; Brandriss et al., 1998; Moschen et al., 2006). These results led to several different suggestions: either that partial dissolution of the diatom frustule occurred during sedimentation, altering $\delta^{18} \mathrm{O}_{\text {diatom }}$ (Brandriss et al., 1998), or that temperature-dependent oxygen isotope fractionation was established during early diagenesis rather than during diatom growth, where ${ }^{16} \mathrm{O}$ from the -Si-OH layer was released forming isotopically enriched Si-O-Si (Schmidt et al., 1997; 2001; Moschen et al., 2006) (Figure 2). At present, the extent to which silica maturation affects the use of $\delta^{18} \mathrm{O}_{\text {diatom }}$ in paleoenvironmental reconstructions remains unknown. However, as long as these isotope exchanges are systematic and predictable within and between taxa, values of $\delta^{18} \mathrm{O}_{\text {diatom }}$ should, at the very least, provide important qualitative 
information for use in paleoenvironmental reconstructions (see Leng and Barker, 2006; Swann and Leng, 2009).

In the lacustrine environments the interpretation of $\delta^{18} \mathrm{O}_{\text {diatom }}$ in terms of paleotemperature also requires an understanding of processes that have opposing effects on the composition of diatom silica. As well as the fractionation between diatom silica and water, described above, values of $\delta^{18} \mathrm{O}_{\text {diatom }}$ are governed by the relationship between the isotopic composition of precipitation entering the lake $(\delta p)$ and atmospheric temperature, the so-called Dansgaard relationship $\delta \mathrm{p} / \mathrm{dT}$ (Dansgaard, 1964). In many lake records the response of $\delta^{18} \mathrm{O}_{\text {diatom }}$ to changes in water temperature will effectively be 'damped' by the opposing effect of variations in the isotope composition of precipitation caused by the Dansgaard relationship. For diatoms the measured isotope composition will, therefore, covary with temperature with an increase of $\sim 0.1$ to $0.4 \% /{ }^{\circ} \mathrm{C}$ (cf., Leng and Marshall, 2004). This assumes that $\delta \mathrm{p} / \mathrm{dT}$ always changes according to the Dansgaard relationship. Whilst it is important to establish the $\delta \mathrm{p} / \mathrm{dT}$ relationship at each site, approximately $+0.6 \%{ }^{\circ} \mathrm{C}$ at intermediate and high latitudes and globally between +0.2 and $+0.7 \% /{ }^{\circ} \mathrm{C}$ (IAEA-WMO GNIP database), in practice deriving any quantitative paleo-temperature/ $\delta \mathrm{p}$ relationship with any certainty is complicated. For example, a Dansgaard relationship is not common in coastal or monsoonal regions or in regions where rainfall comes from two or more air masses. It might therefore be more realistic to use $\delta^{18} \mathrm{O}_{\text {diatom }}$ in areas where there are likely to have been significant changes in the isotope composition of the lake water due to changes in the precipitation/evaporation balance or in the source/amount of precipitation (see below) as change in $\delta^{18} \mathrm{O}_{\text {diatom }}$ due to these factors is normally greater than that due to temperature alone.

In closed (or terminal) lakes, for example, the effect of evaporation on $\delta^{18} \mathrm{O}_{\text {water }}$ will usually be far greater than changes due to temperature or $\delta \mathrm{p}$. Accordingly, $\delta^{18} \mathrm{O}_{\text {water }}$ depends on the balance between the isotope composition of inputs (including the source and amount of precipitation, surface runoff and groundwater inflow) and outputs (evaporation and groundwater loss). Unless there is significant groundwater seepage most closed lakes will lose water primarily through evaporation, the rate of which is controlled by wind speed, temperature and humidity. The phase change of evaporation results in light isotopes of oxygen $\left({ }^{16} \mathrm{O}\right)$ being preferentially evaporated from water bodies leaving water that is relatively enriched in the heavier isotope $\left({ }^{18} \mathrm{O}\right)$. In extreme circumstances, evaporation in the lake catchment area or from the surface of a lake can lead to significantly elevated $\delta^{18} \mathrm{O}_{\text {water }}$ values (Leng et al., 2005). The degree to which evaporation will increase $\delta^{18} \mathrm{O}_{\text {water }}$ depends on the residence time of the lake (lake volume/throughput rate). Changes to a lake's residence time, caused by changes in basin hydrology or varying groundwater fluxes, will also influence the magnitude of enrichment, as 
will changes in the nature of catchment vegetation and soils. These factors have been considered important in the interpretation of a $\delta^{18} \mathrm{O}_{\text {diatom }}$ record from Lake Tilo in East Africa which is interpreted as changes in aridity (Lamb et al., 2005). They showed that the constant supply of solutes from the hydrothermal springs enabled diatoms to grow throughout the year, from which they were able to derive a Holocene lake level which they linked to the amount of evaporation.

Certain $\delta^{18} \mathrm{O}_{\text {diatom }}$ records have been shown to be sensitive to other aspects of climate, such as the amount or source of precipitation (i.e. by recording the isotope composition of precipitation). For example abrupt shifts of up to $18 \%$ in $\delta^{18} \mathrm{O}_{\text {diatom }}$ have been found in a 14,000 year-long record from two alpine lakes on Mount Kenya (Barker et al., 2001), which can not be entirely temperature related given the current knowledge of the diatom-temperature fractionation. Instead the variations have been interpreted as enhanced precipitation related to changes in Indian Ocean sea surface temperatures through the Holocene as measured by alkenone-based sea surface temperature estimates.

There have been several studies of $\delta^{18} \mathrm{O}_{\text {diatom }}$ from lakes in Northern Europe (see Leng and Barker, 2006). These lakes have similarities, in that many are open, through-flow systems with minimal evaporation. Changes in the stratigraphic record of $\delta^{18} \mathrm{O}_{\text {diatom }}$ are interpreted as changes in the summer isotope composition of the lake water. In a pro-glacial lake covering the last 5000 years in Northern Sweden, a $\delta^{18} \mathrm{O}_{\text {diatom }}$ record combined with a sedimentary proxy for glacier fluctuations reflects changes in the isotope composition of summer precipitation (Rosqvist et al., 2004).

In the marine environment, $\delta^{18} \mathrm{O}_{\text {diatom }}$ records can be used to investigate temperature and $\delta^{18} \mathrm{O}_{\text {water }}$ variations in a manner which is similar to that used with $\delta^{18} \mathrm{O}$ records from foraminifera $\left(\delta^{18} \mathrm{O}_{\text {foram }}\right)$ (see Swann and Leng, 2009). This is most prominent in high latitude regions, such as the Southern Ocean, where diatoms are abundant in the sedimentary record due, in part, to the high nutrient concentrations within the water column (see Chapter 22 [Diatoms as indicators of paleoceanographic events] for further information). At these locations changes in $\delta^{18} \mathrm{O}_{\text {diatom }}$ are often dominated by variations in melt water influx from the polar ice caps. For example studies in the Southern Ocean, have revealed periodic decreases of 2-3\% during glacial periods over the last ca. 430,000 years related to melt water events from Antarctica, releasing water containing an inherently lower values of $\delta^{18} \mathrm{O}$ than sea water (Shemesh et al., 1994; 1995; 2002).

At locations where both diatoms and foraminifera co-occur in the sedimentary record, $\delta^{18} \mathrm{O}$ records from the two organisms can extend the wealth of paleoenvironmental information that can be reconstructed. For example, Shemesh et al. (1992) combined $\delta^{18} \mathrm{O}_{\text {diatom }}$ with $\delta^{18} \mathrm{O}_{\text {foram }}$ data, assuming the incorporation of oxygen into the foraminifera calcite shell and diatom frustule occurred in the same 
season and water depth, to calculate changes in Southern Ocean surface paleo- $\delta{ }^{18} \mathrm{O}_{\text {water }}$ and paleotemperature. From this, a ca. $2.0^{\circ} \mathrm{C}$ SST increase was observed in the shift from glacial to Holocene conditions with a concordant $1.2 \pm 0.2 \%$ decrease in $\delta^{18} \mathrm{O}_{\text {water }}$. In another example of combined $\delta^{18} \mathrm{O}_{\text {foram }}$ and $\delta^{18} \mathrm{O}_{\text {diatom }}$ analyses were made on sediments from the North West Pacific Ocean over the onset of major Northern Hemisphere Glaciation, ca. 2.75-2.73 Ma (Haug et al., 2005; Swann et al., 2006). The foraminifera and diatoms over this interval are thought to have lived and precipitated their shells during different seasons, thus providing inter-seasonal information. The $\delta^{18} \mathrm{O}$ record from spring calcifying planktonic foraminifera, for example, indicate a significant, $7.5^{\circ} \mathrm{C}$, cooling of the surface waters at the onset of the Northern Hemisphere Glaciation while an autumnal blooming $\delta^{18} \mathrm{O}_{\text {diatom }}$ record reveals a $4.6 \%$ decrease equating to a significant autumn/early winter freshening and warming of the surface waters.

\subsection{Silicon isotopes}

The availability and concentration of silicic acid (predominantly in the form of $\mathrm{H}_{4} \mathrm{SiO}_{4}$ ) within the water column is a critical factor in diatom cell division and growth. During biomineralization, diatoms take up silicic acid with the lighter ${ }^{28} \mathrm{Si}$ preferentially incorporated into the frustule over the heavier ${ }^{29} \mathrm{Si}$ and ${ }^{30} \mathrm{Si}$. Accordingly, measurements of $\delta^{30} \mathrm{Si}_{\text {diatom }}\left({ }^{30} \mathrm{Si} /{ }^{28} \mathrm{Si}\right)$ and $\delta^{29} \mathrm{Si}_{\text {diatom }}\left({ }^{29} \mathrm{Si} /{ }^{28} \mathrm{Si}\right.$ ) (there is a mass dependent fractionation between the 2 ratios of $\delta^{30} \mathrm{Si}=1.96 \times \delta^{29} \mathrm{Si}$, measurement of both ratios is a good analytical indicator of sample purity but generally only $\delta^{30} \mathrm{Si}_{\text {diatom }}$ is reported), provide information on the availability and rate of silicic acid utilization within the photic zone, which can in turn be related to the global silicon cycle. Importantly, work has indicated that the diatom silicon isotope enrichment factor of $-1.1 \%$ to $-1.9 \%$ is independent of temperature, $\mathrm{pCO}_{2}$ or other interspecies effects (Spadaro 1983; De La Rocha et al., 1997, 2000; Milligan et al., 2004; Varela et al., 2004).

With diatoms representing ca. $40 \%$ of all marine primary productivity (Nelson et al., 1995), the information provided by marine records of $\delta^{30} \mathrm{Si}_{\text {diatom }}$ on diatom productivity and export production aids attempts to understand the role of the biological pump in transferring carbon into the deep ocean and controlling atmospheric concentrations of $\mathrm{CO}_{2}$ (Brzezinski et al., 2002; Matsumoto et al., 2002; Sigman and Haug, 2003; Dugdale et al., 2004). Caution is required, however, in interpreting $\delta^{30} \mathrm{Si}_{\text {diatom }}$ when changes in nutrient concentrations and other environmental parameters may alter diatom silicon uptake, such as may occur during iron fertilization/nutrient limitation (Hutchins and Bruland, 1998; 
Takeda, 1998) and when individual water masses containing different values of $\delta^{30} \mathrm{Si}_{\mathrm{DSi}}$ become mixed e.g. highly fractionated surface water and less fractionated deep water (Reynolds et al., 2006a).

In order to fully interpret changes in $\delta^{30} \mathrm{Si}_{\text {diatom }}$ an understanding is required of the global silicon cycle, its spatial and temporal variability as well as its impact on the isotopic controls of $\delta^{30} \mathrm{Si}_{\mathrm{DSi}}$. For example, changes in the marine $\delta^{30} \mathrm{Si}_{\mathrm{DSi}}$ are a global function of both oceanic and terrestrial silicon inputs and outputs, biogenic cycling of silicic acid, and the interaction of biogenic cycling with the global thermohaline circulation. Similarly, lacustrine $\delta^{30} \mathrm{Si}_{\mathrm{DSi}}$ will be a function of catchment geology, river input, weathering, water residence time as well as the nature and timing of seasonal diatom blooms. To this end, over the past decade research has increasingly focused on examining the contemporary global silicon isotope cycle from both a terrestrial (De La Rocha et al., 2000), riverine (Georg et al., 2006a), groundwater (Georg et al., 2009), marine (Varela et al., 2004) and model perspective (Wischmeyer et al., 2003; De La Rocha and Bickle, 2005). Within the marine system, for example, it has been shown that values of $\delta^{30} \mathrm{Si}_{\mathrm{DSi}}$ range from $+0.5 \%$ to $+3.2 \%$ (De La Rocha et al., 2000; Varela et al., 2004; Cardinal et al., 2005; Reynolds et al., 2006a). Whilst regional offsets in $\delta^{30} \mathrm{Si}_{\mathrm{DSi}}$ of up to $0.4 \%$ have been observed between Atlantic and Pacific deep waters, sediment records of $\delta^{30} \mathrm{Si}_{\text {diatom }}$ suggest that these offsets are constant over glacial-interglacial cycles (De La Rocha et al., 1998; 2002).

To date, few studies have investigated $\delta^{30} \mathrm{Si}_{\text {diatom }}$ in lakes (Alleman et al., 2005; Street-Perrott et al., 2008). In contrast, a number of studies have published results from marine sediment cores to reconstruct changes in nutrient utilization. Research to date includes evidence of a $0.7 \%$ o lowering of $\delta^{30} \mathrm{Si}_{\text {diatom }}$ in the Southern Ocean during the last glacial relative to the Holocene which coincides with reductions in diatom productivity and bulk organic $\delta^{13} \mathrm{C}$ (De La Rocha et al., 1998). Subsequent work has revealed similar $\delta^{30} \mathrm{Si}_{\text {diatom }}$ trends in the Southern Ocean over the last three glacial-interglacial cycles (Brzezinski et al., 2002). Evidence of a strong anti-correlation between $\delta^{30} \mathrm{Si}_{\text {diatom }}$ and bulk sediment $\delta^{15} \mathrm{~N}$, as well as nitrogen diatom isotope records (see Section 2.3.2), over this interval has raised the possibly of an iron enrichment in the Southern Ocean during the last glacial, stimulating increased diatom uptake of nitrate $\left(\mathrm{NO}_{3}{ }^{-}\right)$over silicic acid. This decreased usage of silicon during glacials would have resulted in the development of a concentrated pool of silicic acid across the Southern Ocean. Under the "silicic acid leakage hypothesis" any northward migration of this pool would have enabled diatoms to dominate at lower latitudes than today, potentially increasing the net drawdown of $\mathrm{CO}_{2}$ into the ocean and contributing towards the lower concentrations of atmospheric $p \mathrm{CO}_{2}$ that existed during glacials (Brzezinski et al., 2002; Matsumoto et al., 2002). However, whilst 
evidence exists for higher values of $\delta^{30} \mathrm{Si}_{\text {diatom }}$ in the sub-Antarctic sector of the Southern Ocean during the last glacial, supporting the silicic acid leakage hypothesis, no similar change is apparent in cores from the sub-tropics (Crosta et al., 2005, 2007; Beucher et al., 2007). This makes it unclear to what extent any silicic acid from the Southern Ocean escaped into the sub-tropics and raises questioned over the role of the biological pump in the region in controlling long-term variations in atmospheric $\mathrm{CO}_{2}$.

\subsection{Organic carbon and nitrogen isotopes}

During photosynthesis organic matter, in the form of long chained polyamides and polycationic peptides (Kröger et al., 1999, 2000, 2002), is deposited within the diatom frustule which can be analyzed for both carbon $\left(\delta^{13} \mathrm{C}_{\text {diatom }}\right)$ and nitrogen $\left(\delta^{15} \mathrm{~N}_{\text {diatom }}\right)$ isotopes. Provided that all external organic matter surrounding the frustule can be removed, measurements of $\delta^{13} \mathrm{C}_{\text {diatom }}$ and $\delta^{15} \mathrm{~N}_{\text {diatom }}$ can be utilized to reconstruct changes in nutrient utilization, productivity, $\mathrm{pCO}_{2}$ and the processes which control these changes, e.g. nutrient delivery/utilization, water column stratification and sea-ice coverage. Although suitable for use with lacustrine diatoms (e.g. King et al., 2006), most records of $\delta^{13} \mathrm{C}_{\text {diatom }}$ and $\delta^{15} \mathrm{~N}_{\text {diatom }}$ have to date been constrained to marine systems.

\subsubsection{Carbon isotopes}

During photosynthesis Dissolved Inorganic Carbon (DIC) from the water column, in the form of both dissolved aqueous $\mathrm{CO}_{2}\left(\mathrm{CO}_{2(\mathrm{aq})}\right)$ and $\mathrm{HCO}_{3}{ }^{-}$, are incorporated into the intrinsic organic matter of the diatom frustule (see Laws et al., 1997; Burkhardt et al., 2001; Morel et al., 2002; Roberts et al., 2007). The composition of $\delta^{13} \mathrm{C}_{\text {diatom }}$ is primarily controlled by the balance between the supply and biological demand for DIC as well as the concentration of $\mathrm{CO}_{2(\mathrm{aq})}$ within the photic zone. Diatoms, in line with other organisms, preferentially uptake ${ }^{12} \mathrm{C}$ over ${ }^{13} \mathrm{C}$. As photosynthetic carbon demand for diatoms and other organisms increases, a progressive depletion in ${ }^{12} \mathrm{C}_{\mathrm{DIC}}$ occurs, lowering $\delta^{13} \mathrm{C}_{\mathrm{DIC}}$ whilst leading to higher values of $\delta^{13} \mathrm{C}_{\text {diatom }}$ (Laws et al., 1995, 1997; Bidigare et al., 1999; Rosenthal et al., 2000). The extent to which diatoms preferentially use ${ }^{12} \mathrm{C}$ over ${ }^{13} \mathrm{C}$, however, is a function of $\mathrm{CO}_{2 \text { (aq) }}$ concentration with an increase in $\mathrm{CO}_{2 \text { (aq) }}$ leading to a decrease in $\delta^{13} \mathrm{C}_{\text {diatom }}$ and vice-versa (Freeman and Hayes, 1992; Laws et al., 1995, 1997; Rau et al., 1997; Popp et al., 1999). In interpreting records of $\delta^{13} C_{\text {diatom, }}$, further consideration is required as to the isotopic composition of the $\delta^{13} \mathrm{C}_{\text {DIC }}$ substrate used during photosynthesis which may be altered by changes in ocean circulation, upwelling/stratification, the influx of terrestrial/riverine material and the dissolution of diatoms and other organisms in the photic zone, releasing ${ }^{12} \mathrm{C}$ enriched carbon into the water column. 
A number of other factors including cell shape and size, metabolic pathways, water temperature, and other inter-species vital effects may also lead to spatial and temporal changes in $\delta^{13} \mathrm{C}_{\text {diatom }}$ (Laws et al., 1995; Popp et al., 1998; Burkhardt et al., 1999, 2001; Riebesell et al., 2000; Jacot des Combes et al. 2008). However, provided the influence of these factors on $\delta^{13} \mathrm{C}_{\text {diatom }}$ can be accounted for, changes in $\delta^{13} \mathrm{C}_{\text {diatom }}$ can be employed to reconstruct changes in paleoproductivity and $\mathrm{CO}_{2(\mathrm{aq})}$, and so changes in $\mathrm{pCO}_{2}$. For example, assuming the atmosphere and surface water are in equilibrium, Crosta and Shemesh (2002) calculated that 3\%o and 1\%o of the measured 4\%o difference in $\delta^{13} \mathrm{C}_{\text {diatom }}$ between the last glacial and modern day are attributable to changes in productivity and $p \mathrm{CO}_{2}$ respectively. Similarly, results in Crosta et al. (2005) and Schneider-Mor et al. (2005; 2008) detail change in $\delta^{13} \mathrm{C}_{\text {diatom }}$ in the Southern Ocean over the last $640 \mathrm{ka}$ also related to changes in productivity, nutrient availability and $p \mathrm{CO}_{2}$ concentrations.

\subsubsection{Nitrogen isotopes}

As with carbon, during biomineralization, the lighter ${ }^{14} \mathrm{~N}$ isotope is preferentially assimilate into the diatom organic matter, relative to ${ }^{15} \mathrm{~N}$, from dissolved $\mathrm{NO}_{3}{ }^{-}$within the water column. The exact magnitude of nitrogen isotopic discrimination by diatoms has been shown to vary significantly, from ca. $3 \%$ to ca. $15 \%$, according to changes in growth rates and light availability as well as cell size and shape (Karsh et al., 2003; Needoba et al., 2003; Needoba and Harrison, 2004) whilst tentative evidence of a possible inter-species isotope vital effect has also been identified in fossilized samples from the Southern Ocean (Jacot des Combes et al., 2008). However, with increased uptake of $\mathrm{NO}_{3}{ }^{-}$resulting in

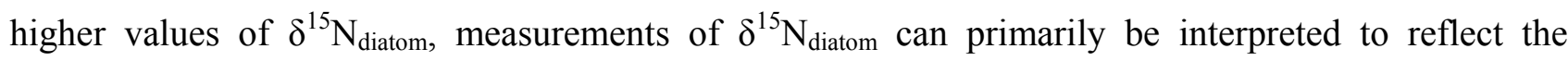
magnitude of nitrate utilization in the photic zone (Shemesh et al., 1993). This must again be balanced by processes that may alter the relative supply or demand of $\mathrm{NO}_{3}{ }^{-}$in the photic zone, for example changes in water column stratification and deep water upwelling (e.g. Robinson et al., 2005; Brunelle et al., 2007; Robinson and Sigman, 2008). In particular, it has been demonstrated that significant variations in diatom cellular nitrogen demand can be caused by changes in iron availability within the photic zone (Hutchins and Bruland, 1998; Takeda, 1998).

Interest in the use of $\delta^{15} \mathrm{~N}_{\text {diatom }}$ has been focused around its application as an alternative to bulk sediment measurements of $\delta^{15} \mathrm{~N}$ to reconstruct changes in the marine nitrogen cycle. Whilst bulk $\delta^{15} \mathrm{~N}$ measurements have provided valuable environmental information (e.g. Altabet and Francois, 1994), questions have been raised as to the extent to which sedimentary records have been altered by diagenesis (Sigman et al., 1999). In addition, the multitude of processes and individual organisms 
which may contribute towards bulk $\delta^{15} \mathrm{~N}$ can prevent both precise and accurate isotope interpretations.

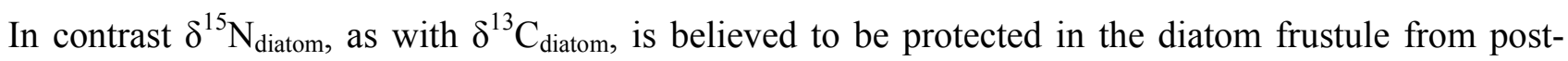
depositional changes whilst also providing an organism specific and therefore more precise insight of changes in the nitrogen cycle (Shemesh et al., 1993).

Existing, records of $\delta^{15} \mathrm{~N}_{\text {diatom }}$ have primarily been generated on sediment core material from the Southern Ocean (e.g. Crosta and Shemesh, 2002; Crosta et al., 2005; Schneider-Mor et al., 2005, 2008)

where changes in $\delta^{15} \mathrm{~N}_{\text {diatom }}$ have been shown to be anti-correlated with those in $\delta^{30} \mathrm{Si}_{\text {diatom }}$ (Beucher et al., 2007). The increased usage of nitrate documented in these studies during glacial periods has been used to provide further support for the silicic acid leakage hypothesis (see Section 2.2). Elsewhere, measurements of $\delta^{15} \mathrm{~N}_{\text {diatom }}$ in the Bering Sea on samples dating back to ca. $120 \mathrm{ka}$ BP have been found to be 3\% higher during the last glacial (Brunelle et al., 2007). These changes have been linked to a stronger water column stratification during the last glacial which, reduced the overall supply and availability of nitrate to the photic zone and triggered an increase in $\delta^{15} \mathrm{~N}_{\text {diatom }}$ as the isotopically lighter ${ }^{14} \mathrm{~N}$ is progressively removed by continuing biological productivity.

\section{Concentration and Purification}

A pre-requisite for all diatom isotope analyses is to ensure samples are free from all sources of nondiatom contamination as most contaminants contain oxygen, silicon and/or organic matter. Natural diatomites ( $>80 \%$ diatom silica) are the easiest material to work with. Although relatively rare, they do occur in some lakes and parts of the World's oceans (North Pacific and Southern Ocean) where the influence of coastlines or fluvial inputs and concentrations of mineral flux are low. Separating pure diatoms even from diatomites can be challenging, especially when diatoms are intermixed with silt, clay, tephra, carbonates and organic matter (Figure 3). In particular, sediment grains can become "trapped" (Figure 3a) within the diatom frustule (which protects them from removal) and clays can become coated with sub micron scale fragmented/broken diatom (Figure 3c) material (adhering by electrostatic charge) (Brewer et al., 2008). To remove these and other contaminants from diatom samples, a number of chemical and physical clean-up methodologies have been used (e.g. JuilletLeclerc, 1986; Shemesh et al., 1988; Shemesh et al., 1995; Singer and Shemesh, 1995; Morley et al., 2004; Rings et al., 2004; Swann et al., 2006; Tyler et al., 2007; Crespin et al., 2008). The success of the purification process is controlled by factors such as: (a) the ability of chemical reagents to fully oxidize certain components (e.g. organics and carbonates), (b) the diatoms and contaminants having different grain sizes and being present in the sample as discrete grains, and (c) that there is sufficient density 
contrast between diatoms and the contaminants to enable density separation. In addition, a prerequisite is that the isotopic composition of the diatom is not altered by the cleaning process. Carbonates and organic materials are generally removed by chemical methods $\left(\mathrm{HCl}, \mathrm{H}_{2} \mathrm{O}_{2}, \mathrm{HNO}_{3}\right)$, clays by sieving at 5 or $10 \mu \mathrm{m}$, and silt-sand sized grains by differential settling techniques using specific gravity and other physical property differences between diatom silica and the contaminant. Shemesh et al. (1995 and subsequent papers) described a similar methodology but added a heavy liquid settling stage to separate diatoms from remaining clastic grains. This heavy liquid stage has been widely adopted and usually involves mixing and centrifuging samples with sodium polytungstate (SPT) at specific gravity of ca. $2.2 \mathrm{~g} / \mathrm{ml}$. Because diatoms have a specific gravities of ca. $2.1 \mathrm{~g} / \mathrm{ml}$ while typical silicate contaminants all tend to be denser than this (quartz, feldspars, micas, clay minerals), the use of SPT allows the density separation of the two components.

An alternative approach to heavy liquid separation for cleaning diatom samples is gravitational split-flow thin fractionation (SPLITT) (Giddings, 1985; Schleser et al., 2001; Rings et al., 2004). SPLITT works by introducing a sample into water under laminar flow which separates the sample into two components according to their density and hydrodynamic properties. Whilst SPLITT is repetitious, requiring each sample to be repeatedly passed through the device to ensure purification, the procedure results in high throughput, small losses and sometimes the ability to isolate specific taxa (where they have different size, density and/or shape) (Leng and Barker 2006). SPLITT also avoids the need to introduce products other than water into the sample. For example, Morley et al. (2004) show that the heavy liquid can contaminate diatom oxygen isotope ratios if not fully removed prior to analysis by sieving at a fine $(\leq 5 \mu \mathrm{m})$ size fraction.

A number of additional chemical cleaning stages may be employed as a final purification stage, such as the addition of potassium permanganate, nitric acid, HF or other alkaline solutions to remove remnants of external organic material and to etch the surficial silica layer in an attempt to disassociate any clays adhering to the diatoms (e.g. van Bennekom and van der Gaast, 1976; Juillet-Leclerc, 1986).

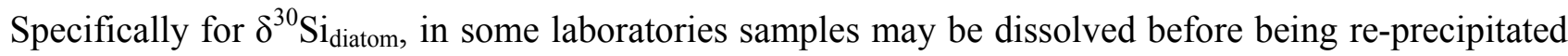
using HF and Triethylamine molybdate to further purify the sample as well as to remove any organic matter prior to analysis (De La Rocha et al., 1996).

Given the small amount of organic matter within the diatom frustule, a series of additional steps, involving the use of oxidizing chemicals, are undertaken to ensure that all external organic matter is removed when analyzing $\delta^{13} \mathrm{C}_{\text {diatom }}$ or $\delta^{15} \mathrm{~N}_{\text {diatom. }}$. The choice of cleaning technique is not know

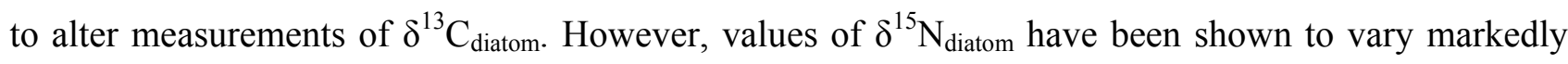


according to the method employed. For example, the work conducted by Shemesh et al. (1993) and Singer and Shemesh (1995) which led to the development of $\delta^{15} \mathrm{~N}_{\text {diatom }}$ as a paleoenvironmental proxy used a concentrated $\mathrm{HNO}_{3} / \mathrm{HClO}_{4}$ mixture. Sigman et al. (1999) demonstrated that this results in

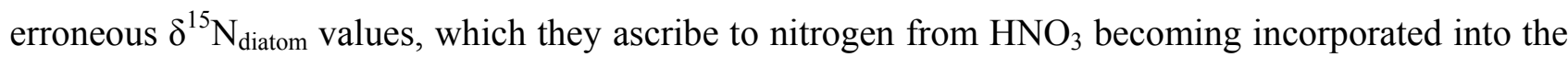
frustule. Whilst the validity of this has been questioned by researchers continuing to use $\mathrm{HNO}_{3} / \mathrm{HClO}_{4}$ mixtures (e.g. Crosta and Shemesh, 2002; Schneider-Mor et al., 2005), the 2-3 times higher diatom \%N values in these studies compared to non- $\mathrm{HNO}_{3}$ studies suggests that there are still unresolved issues associated with the use of $\mathrm{HNO}_{3}$. As an alternative, samples can be cleaned using concentrated perchloric acid or $\mathrm{H}_{2} \mathrm{O}_{2}$ combined with an $\mathrm{HClO}_{4}$ oxidation and dithionite-citric acid reduction cleaning stage (Robinson et al., 2004; 2005; Brunelle et al., 2007).

It is apparent that no single method of diatom purification is suitable for all sediment samples. Instead, the clean-up approach should be adapted to fit each type of sample with the optimal procedure usually found by a combination of trial and error, using the various techniques described above, combined with petrological examination of every sample at each stage. Traditionally, the level of contamination within a sample is assessed visually using point-counting techniques (Morley et al., 2004). However, Brewer et al. (2008) have suggested that more reliable estimates of contamination can be obtained by analysing the trace element geochemistry of purified samples, for example using Scanning Electron Microscopy (SEM) plus Energy Dispersive X-ray Spectroscopy (EDS), X-ray Fluorescence (XRF) or Inductively Coupled Plasma Atomic Emission Spectroscopy (ICP-AES). By measuring the concentrations of compounds such as $\mathrm{Al}_{2} \mathrm{O}_{3}$ and $\mathrm{CaO}$ and comparing these to (published) diatom and clay minerals elemental concentrations, the relative proportion and type of residual contamination can be established for the sample being analysed (Lamb et al., 2007; Brewer et al., 2008). Regardless of the method used to check sample purity, samples containing more than a few percent contamination should be re-cleaned. Where further cleaning does not improve the sample purity, mass-balance corrections can be applied to correct for the effects of non-diatom contaminants following isotope analysis. For example Morley et al. (2005), analysing changes in $\delta^{18} \mathrm{O}_{\text {diatom }}$ in Lake Baikal, showed that even after purification, diatom concentrations in "cleaned" Lake Baikal sediments ranged from $33 \%$ to $99 \%$ with $\delta^{18} \mathrm{O}$ values between $+14.4 \%$ and $+34.3 \%$. By assuming that the bulk $\delta^{18} \mathrm{O}$ value of the cleaned samples was a linear mixture of oxygen from silt and diatoms, samples were mass balanced corrected to obtain a modelled silt-free value of $\delta^{18} \mathrm{O}_{\text {diatom }}$ using point counting estimates of non-diatom contamination and a average $\delta^{18} \mathrm{O}$ value of silt of $+12.3 \%$ (Brewer et al., 2008). To date this modeling approach has not been applied to analyses of $\delta^{30} \mathrm{Si}_{\text {diatom, }} \delta^{13} \mathrm{C}_{\text {diatom }}$ or $\delta^{15} \mathrm{~N}_{\text {diatom }}$ data. 
Whilst mass-balance corrections contain several limitations, such as making assumptions over the amount of silt/contamination to diatom oxygen in each sample, it is one of the few non-destructive ways of correcting for the influence of contaminants so long as a small amount of the cleaned diatom sample is left after isotope analysis to measure the isotopic composition of the contaminants.

\section{Analytical Methods}

\subsection{Oxygen isotopes}

Due to the presence of contaminant oxygen, the outer -Si-OH, hydrous layer of the diatom frustule needs to be removed or accounted for prior to isotope analysis, for example by using oxidising reagents and/or high temperatures (see Section 2.1). Extraction of the -Si-OH layer requires the removal or exchange of 7-40\% of all oxygen within a diatom (Knauth, 1973; Labeyrie, 1979; Labeyrie and Juillet, 1982; Leng et al., 2001; Leng and Sloane, 2008; Swann et al., 2008). Early attempts to remove the oxygen in the -Si-OH layer involved dehydrating samples under vacuum (Mopper and Garlick, 1971; Labeyrie, 1974, 1979). Although the analytical reproducibility and accuracy of the vacuum dehydration method improved with time, the $\delta^{18} \mathrm{O}_{\text {diatom }}$ signal was thought to be contaminated in part due to partial isotopic exchange during sample dehydration (Labeyrie, 1979; Labeyrie and Juillet, 1980, 1982). At present, three reliable techniques have been established which fully account for the -Si-OH layer and permit paleoenvironmental reconstructions from $\delta^{18} \mathrm{O}_{\text {diatom: }}$ Controlled Isotope Exchange (CIE) followed by fluorination (Labeyrie and Juillet, 1982; Juillet-Leclerc and Labeyrie, 1987), Stepwise Fluorination (SWF) (Haimson and Knauth 1983; Matheney and Knauth 1989) and inductive HighTemperature carbon Reduction (iHTR) (Lücke et al., 2005). The amount of diatom material required for each technique varies, the critical factor being whether the mass spectrometry is online or offline and, in theory, the relative size of the diatom -Si-OH layer. Typically, between $1.5 \mathrm{mg}$ and $6.5 \mathrm{mg}$ of diatoms is required for a single analysis.

Under CIE, oxygen in the -Si-OH layer of the diatom is exchanged with water containing a known $\delta^{18} \mathrm{O}$ ratio (Labeyrie and Juillet, 1982; Juillet-Leclerc and Labeyrie, 1987; Crespin et al., 2008). After vacuum heating at $1000^{\circ} \mathrm{C}$ to remove the oxygen in the $-\mathrm{Si}-\mathrm{OH}$ layer, samples are reacted with a fluorine regent to dissociate the tetrahedrally bonded oxygen within the frustules before analysis using standard gas source Isotope Ratio Mass Spectrometry (IRMS) techniques. Mass-balance corrections are then applied to correct for any of the labelled water not removed under vacuum.

SWF techniques involve the use of a fluorine reagent and heat (using a furnace or laser) to extract the oxygen from the different layers of the diatom frustule in separate stages, thereby avoiding 
contamination between the oxygen in the -Si-OH and Si-O-Si layers (Haimson and Knauth, 1983; Thorliefson, 1984; Matheney and Knauth, 1989). Using adaptations of the fluorination procedures established by Taylor and Epstein (1962) and Epstein and Taylor (1971), the -Si-OH layer is initially stripped away leaving behind the inner Si-O-Si layer. A second fluorination stage is then used to liberate oxygen from the Si-O-Si layer (see Leng and Sloane (2008)).

Whilst both CIE and SWF have produced comparable results, using either conventional furnace or laser heating, it has been suggested that measurements from CIE have to be calibrated against SWF due to concerns over incomplete oxygen exchange between the -Si-OH layer and the labelled water under CIE (Schmidt et al., 1997). However, a significant problem of both the CIE and SWF techniques is the requirement for fluorine based oxidising reagents, which have specific health and safety requirements (Leng and Sloane 2008). The inductive High Temperature carbon Reduction (iHTR) method for analysing $\delta^{18} \mathrm{O}_{\text {diatom }}$ eliminates the need for a fluorine-based reagent (Lücke et al., 2005). In iHTR, diatoms are mixed with graphite and heated under vacuum to volatilise any sample contaminants and remove the $-\mathrm{Si}-\mathrm{OH}$ layer. Further heating of the sample to $1,550^{\circ} \mathrm{C}$ results in oxygen from the $\mathrm{Si}$ $\mathrm{O}-\mathrm{Si}$ bonds being converted to $\mathrm{CO}$ for either continuous or offline mass spectrometry.

\subsection{Silicon isotopes}

Similar to $\delta^{18} \mathrm{O}_{\text {diatom, }}$, recent years have been marked by the development and refinement of a range of

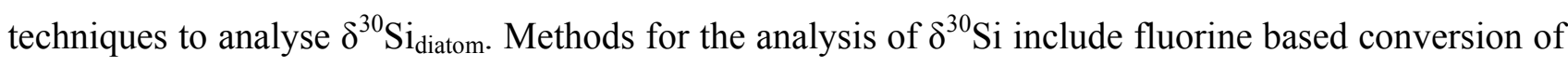
purified silica into $\mathrm{SiF}_{4}$ and IRMS (De Freitas et al., 1991; De La Rocha et al., 1996; Ding et al., 1996; Leng and Sloane, 2008), Multicollector Inductively Coupled Plasma Mass Spectrometry (MC-ICP-MS) (De La Rocha 2002; Cardinal et al., 2003; Reynolds et al., 2006b), acid decomposition and IRMS (Brzezinksi et al., 2006) or ion microprobe analysis (e.g. Basile-Doelsch et al. (2005)). Analytical reproducibility for the most commonly used methods, fluorination and MC-ICP-MS are similar at ca. $0.1 \%$ o $(1 \sigma)$ (Reynolds et al., 2007).

Fluorination methods are based around techniques used for early $\delta^{30} \mathrm{Si}$ measurements of mineral and lunar samples (Epstein and Taylor 1970a, b). This involves the conversion of silicate into $\mathrm{SiF}_{4}$ using a fluorine reagent and is similar to the SWF method used for analyzing $\delta^{18} \mathrm{O}_{\text {diatom. However, since }}$ $\delta^{30} \mathrm{Si}_{\text {diatom }}$ is homogeneous across the diatom frustule, no pre-fluorination stage is required unless oxygen for $\delta^{18} \mathrm{O}_{\text {diatom }}$ is being extracted from the same sample. A recent advancement is the development of a SWF technique which allows for the $\delta^{18} \mathrm{O}_{\text {diatom }}$ and $\delta^{30} \mathrm{Si}_{\text {diatom }}$ signal to be collected simultaneously from the same sample (Leng and Sloane, 2008). Following liberation and collection of 
the oxygen, the silicon can be collected as a by-product of the fluorination reaction as $\mathrm{SiF}_{4}$. This is an important step given the large (milligrams) amounts of material normally required for $\delta^{18} \mathrm{O}_{\text {diatom }}$ and $\delta^{30} \mathrm{Si}_{\text {diatom }}$ analysis using fluorination techniques and opens the possibility of combining information on surface water oceanographic and climate conditions $\left(\delta^{18} \mathrm{O}_{\text {diatom }}\right)$ with information on photic zone nutrient utilization $\left(\delta^{30} \mathrm{Si}_{\text {diatom }}\right)$.

MC-ICP-MS, operating in either wet or dry plasma mode, offers the option to avoid using fluorine reagents when analysing $\delta^{30} \mathrm{Si}_{\text {diatom }}$ (e.g. De La Rocha, 2002; Cardinal et al., 2003). Through the use of standard-sample-standard bracketing, reliable $\delta^{30} \mathrm{Si}$ measurements can be obtained with analytical errors under conventional MC-ICP-MS that are either equivalent to or lower than those achieved with IRMS (Cardinal et al., 2003). Further advances in recent years have been made by using an alkaline fusion rather than HF dissolution stage to increase the sensitivity and reduce silicon fractionation during sample introduction (Georg et al., 2006b; van den Boorn et al., 2006). The use of MC-ICP-MS, however, is often limited by the presence of atomic interferences over the Si mass range by, amongst others, $\mathrm{CO}^{+}, \mathrm{NO}^{+}$and $\mathrm{N}_{2}^{+}$and $\mathrm{N}_{2} \mathrm{H}^{+}$. In particular, many mass spectrometers operating at normal resolution experience high intensity interferences over mass 30, including amongst others ${ }^{14} \mathrm{~N}^{16} \mathrm{O}$, requiring that isotope data be reported as $\delta^{29} \mathrm{Si}$ rather than $\delta^{30} \mathrm{Si}$ (Cardinal et al., 2003). Dual analysis of samples through both MC-ICP-MS and IRMS, however, have demonstrated a linear relationship between $\delta^{29} \mathrm{Si}$ and $\delta^{30} \mathrm{Si}$ (De La Rocha 2002) allowing isotope measurements from different laboratories to be compared. The increasing availability of high resolution MC-ICP-MS, however, eliminates the effects of interference and allows direct measurement of $\delta^{30} \mathrm{Si}$ (Georg et al., 2006b; Reynolds et al., 2006a,b). Whilst yet to be widely used in diatom studies, the introduction of laser ablation systems (LA-MC-ICP-MS) is also likely to yield promising results in the near future (e.g. Chmeleff et al., 2008).

In addition to IRMS and MC-ICP-MS, a number of other methods hold significant potential in analysing $\delta^{30} \mathrm{Si}_{\text {diatom. }}$ One is the development of an acid decomposition method for analysing $\delta^{30} \mathrm{Si}$ on a Finnegan Kiel device in which samples are dissolved in $\mathrm{HF}$ before being converted to $\mathrm{SiF}_{4}$ and analysed by IRMS (Brzezinski et al., 2006). Second is Secondary Ions Mass Spectrometry (SIMS). Whilst analyses to date have been restricted to quartz and cosmic spherules rather than diatoms samples (e.g. Alexander et al., 2002; Basile-Doelsch et al., 2005; Robert and Chaussidon, 2006), the ability to analyse small grains $(>50 \mu \mathrm{m})$ opens the possibility that it may become viable to analyse individual frustules. However, in order to achieve this, a reduction in the analytical error associated with SIMS is required, which are currently higher than those of other techniques (Basile-Doelsch et al., 2005). 


\subsection{Carbon/Nitrogen}

Both $\delta^{13} \mathrm{C}_{\text {diatom }}$ and $\delta^{15} \mathrm{~N}_{\text {diatom }}$ can be analyzed simultaneously on the same sample using an elemental analyzer (which also provides $\% \mathrm{C}$ and $\% \mathrm{~N}$ data) attached to a mass spectrometer. Continuous flow or cryogenic trapping methods are used where $\mathrm{CO}_{2}$ and $\mathrm{N}_{2} \mathrm{O}$ are passed from the analyser to the IRMS. The exact details of the analytical protocol varies between individual laboratories (e.g. Shemesh et al., 1993; Crosta and Shemesh, 2002). The coupled elemental analyser-IRMS technique has greatly simplified organic isotope measurements, has dramatically increased sample analysis through put, while also allowing significant reduction in sample size over conventional off-line preparations. Recently a new persulfate-denitrifier technique has been developed specifically for analyzing $\delta^{15} \mathrm{~N}_{\text {diatom }}$ in which organic $\mathrm{N}$ in the frustule is liberated and converted to $\mathrm{N}_{2} \mathrm{O}$ for $\delta^{15} \mathrm{~N}$ analysis (Robinson et al., 2004). Importantly, the persulfate-denitrifier method increases sensitivity and so requires much smaller sample sizes, ca. $5 \mathrm{mg}$ compared to $80-100 \mathrm{mg}$ of diatom for combustion methods. Surprisingly $\mathrm{N}$ yields are lower and $\delta^{15} \mathrm{~N}_{\text {diatom }}$ values, typically, 1-3\%o higher under the persulfate-denitrifier method. At present the reason behind these discrepancies remains unresolved. One explanation is the presence of a contaminant gaseous $\mathrm{N}$ pool trapped within diatoms, which is analyzed during the combustion process but removed prior to isotope analysis with the persulfate-denitrifier method. However, it is also possible that the persulfate-denitrifier method may fail to completely react with all the organic nitrogen within the frustule (De La Rocha, 2006) whilst other "uncontrolled processes" during the persulfatedenitrifier method may result in the formation of other nitrogen compounds, limiting the accuracy of individual persulfate-denitrifier measurements (Crosta et al., 2005). As such, further research is required into the analytical techniques used for $\delta^{15} \mathrm{~N}_{\text {diatom. }}$.

\section{Summary}

Diatom silica is a form of biogenic opal with the structure mainly formed of tetrahedrally bonded Si-OSi molecules surrounded by a hydrous layer of loosely bonded -Si-OH species which can rapidly exchange oxygen with surrounding water. In addition, the frustule contains small amounts of carbon and nitrogen which are commonly thought to occur as intrinsic and sub-micron inclusions of organic matter. Here we show that valuable palaeoenvironmental data can be gained from the oxygen $\left(\delta^{18} \mathrm{O}_{\text {diatom }}\right)$, silicon $\left(\delta^{30} \mathrm{Si}_{\text {diatom }}\right)$, carbon $\left(\delta^{13} \mathrm{C}_{\text {diatom }}\right)$ and nitrogen $\left(\delta^{15} \mathrm{~N}_{\text {diatom }}\right)$ isotope composition of diatom silica, especially since diatoms are abundant in many lakes and found over vast areas of our 
oceans. They are particularly important in areas where other hosts (e.g. carbonates) are absent, such as in high latitude marine and lacustrine regions.

Analysis of the isotope composition of diatom silica requires samples that are almost pure diatomite since analytical techniques will also liberate any contaminants remaining in the sample. Recent studies of $\delta^{18} \mathrm{O}_{\text {diatom }}$ have highlighted this, showing that even a small proportion of contaminant can have a significant influence on the isotope values. While there is a generally accepted protocol for cleaning samples involving chemistry, sieving and settling techniques, and more recently laminar flow separation, all sediments require their own specific procedure and every sample must be scrutinized by microscopy/SEM to check for the level of contamination prior to analysis. Where sediments cannot be purified sufficiently, a semi-quantitative or geochemical assessment of the main contaminants can facilitate mass balance techniques.

Isotope measurements can be obtained by various fluorination and IRMS methods for $\mathrm{O}$ and $\mathrm{Si}$. Alternative methods are being increasingly used for silicon isotopes, namely MC-ICP-MS and SIMS. Analysis of the carbon and nitrogen isotope composition from diatom included organic matter mainly requires combustion within an elemental analyzer and IRMS and are relatively straight forward apart from dealing with the large sample sizes (ca. 30-100 mg). Recent advances, however, have resulted in

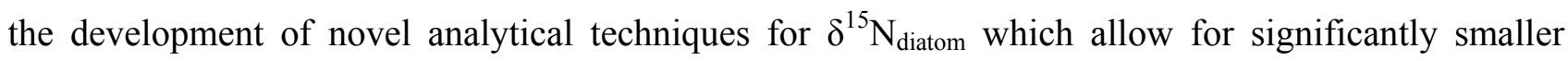
sample (ca. $5 \mathrm{mg}$ ).

\section{Acknowledgements}

Thanks are owed to Elsevier for permission to re-print Fig. 1, and to Robert Moschen and Elsevier for permission to re-print Fig. 2. Funding for GEAS was provided by a NERC postdoctoral fellowship award (NE/F012969/1).

\section{Figures}

Figure 1. Amorphous silica (here used as an analogue for diatom silica). A schematic illustration of the structure of amorphous hydrated silica showing the inner tetrahedrally bonded silica and the outer (readily exchangeable) hydrous layer. Figure reprinted from Leng and Barker (2006), with permission from Elsevier.

Figure 2. Infra-red absorption spectra of diatoms from a laboratory culture and from Lake Holzmaar, Germany, showing the progressive loss of - $\mathrm{Si}-\mathrm{OH}$ groups and the creation of -Si-O-Si bonds as the 
frustule undergo silica maturation during sedimentation/burial. Graph of Cyclotella meneghiniana shows the absorption spectra of a laboratory culture which is similar in transmission to that of sediment trap material. Figure reprinted from Moschen et al. (2006), with permission from Elsevier.

Figure 3. Scanning electron microscopy images of (a) diatom frustules and micron scale grains contained within and around diatoms (Lake Baikal, Russia, sediments), (b) tephra within a diatom sample, which are usually difficult to remove because of electrostatic charge (Lake Tilo, Ethopia, sediments), (c) clays and accumulations of sub-micron scale material within a diatom sample (Lake Baikal sediments), (d) a pure diatom sample from ODP Site 882 in the North West Pacific Ocean, showing good preservation and the absence of submicron fragments. 


\section{References}

Alexander, C. M. O'D., Taylor, S., Delaney, J.S., Ma, P., Herzog, G.F. (2002). Mass-dependent fractionation of $\mathrm{Mg}, \mathrm{Si}$, and $\mathrm{Fe}$ isotopes in five stony cosmic spherules. Geochimica et Cosmochimica Acta, 66, 173-183.

Alleman, L.Y., Cardinal, D., Cocquyt, C., Plisnier, P.D., Descy, J.P., Kimirei, I., Sinyinza, D., and Andre, L. (2005). Silicon isotope fractionation in Lake Tanganyika and its main tributaries. Journal of Great Lakes Research, 31, 509-519.

Altabet M. A. and Francois R. (1994). Sedimentary nitrogen isotopic ratio as a recorder for surface ocean nitrate utilization. Global Biogeochemical Cycles, 8, 103- 116.

Barker, P.A., Street-Perrot, F.A., Leng, M.J., Greenwood, P.B., Swain, D.L., Perrot, R.A., Telford, R.J. and Ficken, K.J. (2001). A 14,000-Year oxygen isotope record from diatom silica in two alpine lakes on Mt. Kenya. Science, 292, 2307-2310.

Basile-Doelsch, I., Meunier, J.D. and Parron, C. (2005). Another continental pool in the terrestrial silicon cycle. Nature, 433, 399-402.

Bemis, B.E., Spero, H., Bijma, J., and Lea, D.W. (1998). Reevaluation of the oxygen isotopic composition of planktonic foraminifera: experimental results and revised paleotemperature equations. Paleoceanography, 13, 150-160.

Beucher, C.P., Brzezinski, M.A., and Crosta, X. (2007). Silicic acid dynamics in the glacial subAntarctic: Implications for the silicic acid leakage hypothesis. Global Biogeochemical Cycles, 21, GB3015, doi:10.1029/2006GB002746.

Bidigare, R.R., Hanson, K.L., Buesseler, K.O., Wakeham, S.G., Freeman, K.H., Pancost, R.D., Millero, F.J., Steinberg, P., Popp, B.N., Latasa, M., Landry, M.R. and Laws, E.A. (1999). Iron stimiulated change in ${ }^{13} \mathrm{C}$ fractionation and export by equatorial Pacific phytoplankton: towards a paleogrowth rate proxy. Paleoceanography, 14, 589-595.

Binz P. (1987). Oxygen-isotope analysis on recent and fossil diatoms from Lake Walen and Lake Zurich (Switzerland) and its application on paleoclimatic studies. Unpublished Ph.D. thesis, Swiss Federal Institute of Technology, Zurich.

Brandriss, M.E., O'Neil, J. R., Edlund, M.B., Stoermer, E.F. (1998). Oxygen isotope fractionation between diatomaceous silica and water. Geochimica et Cosmochimica Acta, 62, 1119-1125.

Brewer, T.S., Leng, M.J., Mackay, A.W., Lamb, A.L., Tyler, J.J., and Marsh, N.G. (2008). Unravelling contamination signals in biogenic silica oxygen isotope composition: the role of major and trace element geochemistry. Journal of Quaternary Science, 23, 321-330.

Brunelle, B.G., Sigman, D.M., Cook, M.S., Keigwin, L.D., Haug, G.H., Plessen, B., Schettler, G. and Jaccard, S.L. (2007). Evidence from diatom-bound nitrogen isotopes for subarctic Pacific stratification during the last ice age and a link to North Pacific denitrification changes. Paleoceanography, 22, doi:10.1029/2005PA001205. 
Brzezinski, M.A., Pride, C.J., Franck, V.M., Sigman, D.M., Sarmiento, J.L., Matsumoto, K., Gruber, N., Rau, G.H. and Coale, K.H. (2002). A switch from $\mathrm{Si}(\mathrm{OH}) 4$ to NO3-depletion in the glacial Southern Ocean. Geophysical Research Letters, 29, 1564, doi: 10.1029/2001GL014349.

Brzezinski, M.A., Jones, J.L., Beucher, C.P. and Demarest, M.S. (2006). Automated determination of silicon isotope natural abundance by the acid decomposition of cesium hexafluosilicate. Analytical Chemistry, 78, 6109-6114.

Burkhardt, S., Riebesell, U., and Zondervan, I. (1999). Effects of growth rate, $\mathrm{CO}_{2}$ concentration, and cell size on the stable carbon isotope fractionation in marine phytoplankton. Geochimica et Cosmochimica Acta, 63, 3729-3741.

Burkhardt, S., Amoroso, G., Riebesell, U. and Sültemeyer, D. (2001). $\mathrm{CO}_{2}$ and $\mathrm{HCO}_{3}{ }^{-}$uptake in marine diatoms acclimated to different $\mathrm{CO} 2$ concentrations. Limnology and Oceanography, 46, 13781391.

Cardinal, D., Allegan, L.Y., de Jong, J., Ziegler, K. and André, L. (2003). Isotopic composition of silicon measured by multicollector plasma source mass spectrometry in dry plasma mode. Journal of Analytical Atomic Spectrometry, 18, 213-218.

Cardinal, D., Alleman, L.Y., Dehairs, F., Savoye, N., Trull, T.W. and André, L. (2005). Relevance of silicon isotopes to Si-nutrient utilization and Si-source assessment in Antarctic waters. Global Biogeochemical Cycles, 18, GB2007. doi: 10.1029/2004GB002364.

Chmeleff, J., Horn, I., Steinhoefel, G. and von Blanckenburg, F. (2008). In situ determination of precise stable $\mathrm{Si}$ isotope ratios by UV-femtosecond laser ablation high-resolution multi-collector ICPMS. Chemical Geology, 29, 155-166.

Crespin, J., Alexandre, A., Sylvestre, F., Sonzogni, C., Paillès, C., Garreta, V. (2008). IR laser extraction technique applied to oxygen isotope analysis of small biogenic silica samples. Analytical Chemistry, 80, 2372-2378.

Crosta, X. and Shemesh, A. (2002). Reconciling down core anticorrelation of diatom carbon and nitrogen isotopic ratios from the Southern Ocean. Paleoceanography, 17, 1010. doi: 10.1029/2000PA000565.

Crosta, X., Shemesh, A., Salvignac, M-E., Gildor, H. and Yam, R. (2002). Late Quaternary variations of elemental ratios $(\mathrm{C} / \mathrm{Si}$ and $\mathrm{N} / \mathrm{Si})$ in diatom-bound organic matter from the Southern Ocean. DeepSea Research II, 49, 1939-1952.

Crosta, X., Shemesh, A., Etourneau, J., Yam, R., Billy, I. and Pichon, J.J. (2005). Nutrient cycling in the Indian sector of the Southern Ocean over the last 50,000 years. Global and Biogeochemical Cycles, 19, GB3007, doi:10.1029/2004GB002344.

Crosta, X., Beucher, C., Pahnke, K. and Brzezinski, M.A. (2007). Silicic acid leakage from the Southern Ocean: opposing effects of nutrient uptake and oceanic circulation. Geophysical Research Letters, 34, L13601. doi:10.1029/2006GL029083.

Dansgaard, W. (1964). Stable isotopes in precipitation. Tellus, 16, 436-468. 
De Freitas, A.S.W., McCulloch, A.W. and McInnes, A.G. (1991). Recovery of silica from aqueous silicate solutions via trialkyl or tetraalkylammonium silicomolybdate, Canadian Journal of Chemistry, 69, 611-614.

De La Rocha, C. L. (2002). Measurement of silicon stable isotope natural abundances via multicollector inductively coupled plasma mass spectrometry (MC-ICP-MS). Geochemistry, Geophysics, Geosystems, 3, DOI:10.1029/2002GC000310.

De La Rocha, C. L. (2006). Opal-based isotopic proxies of paleoenvironmental conditions. Global Biogeochemical Cycles, 20, GB4S09. doi:10.1029/2005GB002664.

De La Rocha, C. L. and Bickle, M.J. (2005). Sensitivity of silicon isotopes to whole-ocean changes in the silica cycle. Marine Geology, 217, 267-282.

De La Rocha C.L., Brzezinski M.A. and De Niro M.J. (1996). Purification, recovery and laser-driven fluorination of silicon from dissolved and particulate silica for the measurements of natural stable isotopes abundances. Analytical Chemistry, 68, 3746-3750.

De La Rocha C.L., Brzezinski M.A. and DeNiro M.J. (1997). Fractionation of silicon isotopes by marine diatoms during biogenic silica formation. Geochimica et Cosmochimica Acta, 61, 5051-5056.

De La Rocha C.L., Brzezinski M.A., DeNiro M.J. and Shemesh A. (1998). Silicon-isotope composition of diatoms as an indicator of past oceanic change. Nature, 395, 680-683.

De La Rocha C.L., Brzezinski M.A. and DeNiro M.J. (2000). A first look at the distribution of the stable isotopes of silicon in natural waters. Geochimica et Cosmochimica Acta, 64, 2467-2477.

Ding T., Jiang S., Wan D., Li Y., Li J., Song H., Liu Z. and Yao X. (1996). Silicon Isotope Geochemistry. Geological Publishing House, Beijing, China.

Dugdale, R.C., Lyle, M., Wilkerson, F.P., Chai, F., Barber, R.T. and Peng, T-H. (2004). Influence of equatorial diatom processes on $\mathrm{Si}$ deposition and atmospheric $\mathrm{CO} 2$ cycles at glacial/interglacial timescales. Paleoceanography, 19, PA3011: doi:10.1029/2003PA000929.

Duplessy, J.C., Lalou, C. and Vinot, A.C. (1970). Differential isotopic fractionation in benthic foraminifera and paleotemperatures revised. Science, 213, 1247-1250.

Epstein, S. and Taylor, H.P. (1970a). The concentration and isotopic composition of hydrogen, carbon and silicon in Apollo 11 lunar rocks and minerals. Proceedings of the Apollo 11 lunar science conference, 2, 1085-1096.

Epstein, S. and Taylor, H.P. (1970b). Stable isotopes, rare gases, solar wind and spallation products. Science, 167, 533-535.

Epstein, S. and Taylor, H.P. (1971). $\mathrm{O}^{18} / \mathrm{O}^{16}, \mathrm{Si}^{30} / \mathrm{Si}^{28}, \mathrm{D} / \mathrm{H}$ and $\mathrm{C}^{13} / \mathrm{C}^{12}$ ratios in lunar samples. Proceedings of the second lunar conference, 2, 1421-1441.

Freeman, K. H. and Hayes, J.M. (1992). Fractionation of carbon isotopes by phytoplankton and estimates of ancient $\mathrm{CO}_{2}$ levels. Global Biogeochemical Cycles, 6, 185-198. 
Georg, R.B., Reynolds, B.C., Frank, M. and Halliday, A.N. (2006a). Mechanisms controlling the silicon isotopic compositions of river waters. Earth and Planetary Science Letters, 249, 290-306.

Georg, R.B., Reynolds, B.C., Frank, M. and Halliday, A.N. (2006b). New sample preparation techniques for the determination of Si isotopic compositions using MC-ICPMS. Chemical Geology, 235, 95-104.

Georg, R.B., Zhu, C., Reynolds, B.C. and Halliday, A.N. (2009). Stable silicon isotopes of groundwater, feldspars, and clay coatings in the Navajo Sandstone aquifer, Black Mesa, Arizona, USA. Geochimica et Cosmochimica Acta, 73, 2229-2241.

Giddings, J.C. (1985). A system based on split-flow lateral transport thin (SPLITT) separation cells for rapid and continuous particle fractionation. Separation Science and Technology, 20, 749-768.

Haimson, M. and Knauth, L.P. (1983). Stepwise fluorination - a useful approach for the isotopic analysis of hydrous minerals. Geochimica et Cosmochimica Acta, 47, 1589-1595.

Haug, G.H., Ganopolski, A., Sigman, D. M., Rosell-Mele, A., Swann, G.E.A., Tiedemann, R., Jaccard, S, Bollmann, J., Maslin, M.A., Leng, M.J. and Eglinton, G. (2005). North Pacific seasonality and the glaciation of North America 2.7 million years ago. Nature, 433, 821-825.

Hutchins, D.A. and Bruland, K.W. (1998). Iron-limited diatom growth and Si:N uptake ratios in a coastal upwelling zone. Nature, 393, 561-564.

Jacot des Combes, H., Esper, O., De La Rocha, C.L., Abelmann, A., Gersonde, R., Yam, R. and Shemesh, A. (2008). Diatom $\delta^{13} \mathrm{C}, \delta^{15} \mathrm{~N}$, and $\mathrm{C} / \mathrm{N}$ since the Last Glacial Maximum in the Southern Ocean: Potential Impact of Species Composition. Paleoceanography, 23, PA4209, doi:10.1029/2008PA001589.

Juillet, A. (1980a). Structure de la silice biogenique: nouvelles donnes apportees par l'analyse isotopique de l'oxygene. C.R.Academy of Science, Paris 290.D: 1237-1239.

Juillet, A. (1980b). Analyse isotopique de la silice des diatomees lacustres et marines: fractionnement des isotopes de l'oxygene en fonction de la temperature. Thèse de troisième cycle, Université Paris-Sud XI.

Juillet-Leclerc, A. (1986). Cleaning process for diatomaceous samples. In Proceedings of the 8th Diatom Symposium, ed. M. Ricard, Koeltz Scientific Books, Koenigstein.

Juillet-Leclerc, A. and Labeyrie, L. (1987). Temperature dependence of the oxygen isotopic fractionation between diatom silica and water. Earth and Planetary Science Letters, 84, 69-74.

Karsh, K.L., Trull, T.W., Lourey, M.J. and Sigman, D.M. (2003). Relationship of nitrogen isotope fractionation to phytoplankton size and iron availability during the Southern Ocean Iron RElease Experiment (SOIREE). Limnology and Oceanography, 48, 1058-1068.

King, L., Barker, P.A. and Grey, J. (2006). Organic inclusions in lacustrine diatom frustules as a host for carbon and nitrogen isotopes. Verh. Internat. Verein. Limnol., 29, 1608-1610. 
Knauth, L.P. (1973). Oxygen and hydrogen isotope ratios in cherts and related rocks. Unpublished $\mathrm{Ph} . \mathrm{D}$. thesis, California Institute of Technology.

Kröger, N., Deutzmann, R. and Sumper, M. (1999). Polycationic peptides from diatom biosilica that direct silica nanosphere formation. Science, 286, 1129-1132.

Kröger, N., Deutzmann, R., Bergsdorf, C. and Sumper, M. (2000). Species-specific polyamines from diatoms control silica morphology. Proceedings of the National Academy of Sciences, 97, 14,13314,138 .

Kröger, N., Lorenz, S., Brunner, E. and Sumper, M. (2002). Self-assembly of highly phosphorylated silaffins and their function in biosilica morphogenesis. Science, 298, 584-586.

Labeyrie, L.D. (1974). New approach to surface seawater paleotemperatures using (18)O/(16)O ratios in silica of diatom frustules. Nature, 248, 40-42.

Labeyrie, L.D. (1979). La composition isotopique de l'oxygene de la silice des valves de diatomees. Mise au point d'une nouvelle methode de palaeo-climatologie. Diss. Universitie de Paris XI.

Labeyrie, L.D. and Juillet, A. (1980). Isotopic exchange of the biogenic silica oxygen. Comptes Rendus Hebdomadaires des Seances de L'Academie des Sciences Serie D, 290, 1185-1188.

Labeyrie, L.D. and Juillet, A. (1982). Oxygen isotopic exchangeability of diatom valve silica; interpretation and consequences for palaeoclimatic studies. Geochimica et Cosmochimica Acta, 46, 967-975.

Lamb, A.L., Leng, M.J., Sloane, H.J. and Telford, R.J. (2005). A comparison of the palaeoclimatic signals from diatom oxygen isotope ratios and carbonate oxygen isotope ratios from a low latitude crater lake. Palaeogeography, Palaeoclimatology, Palaeoecology, 223, 290-302.

Lamb, A.L., Brewer, T.S., Leng, M.J., Sloane, H.J. and Lamb, H.F. (2007). A geochemical method for removing the effect of tephra on lake diatom oxygen isotope records. Journal of Paleolimnology, 37, 499-516.

Laws, E. A., Popp, B.N., Bidigare, R.R., Kennicutt, M.C. and Macko, S.A. (1995). Dependence of phytoplankton carbon isotopic composition on growth rate and $\left[\mathrm{CO}_{2}\right]_{\mathrm{aq}}$ : theoretical considerations and experimental results. Geochimica et Cosmochimica Acta, 59, 1131-1138.

Leng, M.J. and Marshall J.D. (2004). Palaeoclimate interpretation of stable isotope data from lake sediment archives. Quaternary Science Reviews, 23, 811-831.

Leng, M. J. and Barker, P.A. (2006). A review of the oxygen isotope composition of lacustrine diatom silica for palaeoclimate reconstruction. Earth Science Reviews, 75, 5-27.

Leng, M.J. and Sloane, H.J. (2008). Combined oxygen and silicon isotope analysis of biogenic silica. Journal of Quaternary Science, 23, 313-319. 
Leng, M.J., Barker, P.A., Greenwood, P., Roberts N. and Reed J. (2001). Oxygen isotope analysis of diatom silica and authigenic calcite from Lake Pinarbasi, Turkey. Journal of Paleolimnology, 25, 343349.

Leng, M.J., Metcalfe, S.E. and Davies, S.J. (2005). Investigating late Holocene climate variability in central Mexico using carbon isotope ratios in organic matter and oxygen isotope ratios from diatom silica within lacustrine sediments. Journal of Paleolimnology, 34, 413-431.

Lücke, A., Moschen, R. and Schleser, G.H. (2005). High temperature carbon reduction of silica: A novel approach for oxygen isotope analysis of biogenic opal. Geochimica et Cosmochimica Acta, 69, 1423-1433.

Matheney, R.K. and Knauth, L.P. (1989). Oxygen-isotope fractionation between marine biogenic silica and seawater. Geochimica et Cosmochimica Acta, 53, 3207-3214.

Matsumoto, K., Sarmiento, J.L. and Brzezinski, M.A. (2002). Silicic acid leakage from the Southern Ocean: A possible explanation for glacial atmospheric pCO2. Global Biogeochemical Cycles, 16, 1031. doi: 10.1029/2001GB001442.

Milligan, A.J., Varela, D.E., Brzezinski, M.A. and Morel, F.M.M. (2004). Dynamics of silicon metabolism and silicon isotopic discrimination in a marine diatom as a function of $p \mathrm{CO}_{2}$. Limnology and Oceanography, 49, 322-329.

Mopper, K. and Garlick, G.D. (1971). Oxygen isotope fractionation between biogenic silica and ocean water. Geochimica et Cosmochimica Acta, 35, 1185-1187.

Morel, F.M.M., Cox, E.H., Kraepiel, A.M.L., Lane, T.W., Milligan, A.J., Schaperdoth, I., Reinfelder, J.R. and Tortell, P.D. (2002) Acquisition of inorganic carbon by the marine diatom Thalassiosira weissflogii. Functional Plant Biology, 29, 301-308.

Morley, D.W., Leng, M.J., Mackay, A.W., Sloane, H.J., Rioual, P. and Battarbee, R.W. (2004). Cleaning of lake sediment samples for diatom oxygen isotope analysis. Journal of Paleolimnology, 31, 391-401.

Morley, D. W., Leng, M.J., Mackay, A.W. and Sloane, H.J. (2005). Late Glacial and Holocene environmental change in the Lake Baikal region documented by oxygen isotopes from diatom silica. Global and Planetary Change, 46, 221-233.

Moschen, R., Lücke, A. and Schleser, G. (2005). Sensitivity of biogenic silica oxygen isotopes to changes in surface water temperature and palaeoclimatology. Geophysical Research Letters, 32, L07708, doi:10.1029/2004GL022167.

Moschen, R., Lücke, A. , Parplies, J., Radtke, U. and Schleser, G.H. (2006). Transfer and early diagenesis of biogenic silica oxygen isotope signals during settling and sedimentation of diatoms in a temperate freshwater lake (Lake Holzmaar, Germany). Geochimica et Cosmochimica Acta, 70, 43674379. 
Needoba, J.A. and Harrison, P.J. (2004). Influence of low light and a light:dark cycle on $\mathrm{NO}_{3}^{-}$uptake, intracellular $\mathrm{NO}_{3}^{-}$, and nitrogen isotope fractionation by marine phytoplankton. Journal of Phycology, 40, 505-516.

Needoba, J.A., Waser, N.A., Harrison, P.J. and Calvert, S.E. (2003). Nitrogen isotope fractionation in 12 species of marine phytoplankton during growth on nitrate. Marine Ecology Progress Series, 255, 81-91.

Nelson, D.M., Tréguer, P., Brzezinski, M.A., Leynaert, A. and Quéguiner, B. (1995). Production and dissolution of biogenic silica in the ocean: revised global estimates, comparison with regional data and relationship to biogenic sedimentation. Global Biogeochemical Cycles, 9, 359-372.

Perry, C.C. (1989). Chemical studies of biogenic silica. In Biomineralization: chemical and biological perspectives, eds S. Mann, J. Webb, and R.J.P. Williams, VCH Verlagsgesellschaft, Weinheim.

Popp, B. N., Laws E.A., Bidigare R.R., Dore J.E., Hanson K.L. and Wakeham, S.G. (1998). Effect of phytoplankton cell geometry on carbon isotopic fractionation. Geochimica et Cosmochimica Acta, 62, 69-77.

Popp, B. N., Trull, T., Kenig, F., Wakeham, S.G., Rust, T.M., Tilbrook, B., Griffiths F.B., Wright S.W, Marchant H.J., Bidigare, R.R. and Laws, E.A. (1999). Controls on the carbon isotopic composition of Southern Ocean phytoplankton. Global Biogeochemical Cycles, 13, 827-843.

Rau, G.H., Riebesell, U. and Wolf-Gladrow, D. (1997) $\mathrm{CO}_{2 \mathrm{aq}}$-dependent photosynthetic ${ }^{13} \mathrm{C}$ fractionation in the ocean: a model versus measurements. Global Biogeochemical Cycles, 11, 267-278.

Reynolds, B.C., Frank, M. and Halliday, A.N. (2006a). Silicon isotope fractionation during nutrient utilization in the North Pacific. Earth and Planetary Science Letters, 244, 431-443.

Reynolds, B.C., Georg, R.B., Oberli, F., Wiechert, U. and Halliday, A.N. (2006b). Re-assessment of silicon isotope reference materials using high-resolution multi-collector ICP-MS. Journal of Analytical Atomic Spectrometry, 21, 266-269.

Reynolds, B.C., Aggarwal, J., Andre, L., Baxter, D., Beucher, C., Brzezinski, M.A., Engstrom, E., Georg, R.B., Land, M., Leng, M.J., Opfergelt, S., Rodushkin, I., Sloane, H.J., van den Boorn, S. H. J. M., Vroon, P.Z. and Cardinal, D. (2007). An inter-laboratory calibration of Si isotope reference materials. Journal of Analytical Atomic Spectrometry, 22, 561-568.

Riebesell, U., Burkhardt, S., Dauelsberg, A. and Kroon, B. (2000). Carbon isotope fractionation by a marine diatom: dependence on the growth-rate-limiting resource. Marine Ecology Progress Series, 193, 295-303.

Rings, A., Lücke, A. and Schleser, G.H. (2004). A new method for the quantitative separation of diatom frustules from lake sediments. Limnology and Oceanography Methods, 2, 25-34.

Robert, F. and Chaussidon, M. (2006). A palaeotemperature curve for the Precambrain oceans based in silicon isotopes in cherts. Nature, 443, 969-972. 
Roberts, K., Granum, E., Leegood R.C. and Raven, J.A. (2007). Carbon acquisition by diatoms. Photosynthesis Research, 93, 79-88.

Robinson, R.S., Brunelle, B.G. and Sigman, D.M. (2004). Revisiting nutrient utilisation in the glacial Antarctic: evidence from a new method for diatom-bound $\mathrm{N}$ isotopic analysis. Paleoceanography, 19, PA3001, doi: 10.1029/2003PA000996.

Robinson, R.S., Sigman, D.M., DiFiore, P.J., Rohde, M.M., Mashiotta, T.A. and Lea, D.W. (2005). Diatom-bound ${ }^{15} \mathrm{~N} /{ }^{14} \mathrm{~N}$ : New support for enhanced nutrient consumption in the ice age subantarctic Paleoceanography, 20, PA3003, doi:10.1029/2004PA001114.

Rosenthal, Y., Dahan, M. and Shemesh, A. (2000). Southern Ocean contributions to glacial-interglacial changes of atmospheric $\mathrm{pCO}_{2}$ : an assessment of carbon isotope record in diatoms. Paleoceanography, 15, 65-75.

Rosqvist, G., Jonsson, C., Yam, R., Karlén, W. and Shemesh, A. (2004). Diatom oxygen isotopes in pro-glacial lake sediments from northern Sweden: a 5000 year record of atmospheric circulation. Quaternary Science Reviews, 23, 851-859.

Sancetta, C., Heusser L., Labeyrie L., Sathy Naidu A. and Robinson S.W. (1985). Wisconsin Holocene paleoenvironment of the Bering Sea: evidence from diatoms, pollen, oxygen isotopes and clay minerals. Marine Geology, 62, 55-68.

Schiff, C., Kaufman, D.S., Wolfe, A.P., Dodd, J. and Sharp, Z. (2009). Late Holocene storm-trajectory changes inferred from the oxygen isotope composition of lake diatoms, south Alaska. Journal of Paleolimnology, 41, 189-208.

Schleser, G.H., Lücke, A., Moschen, R. and Rings, A. (2001). Separation of diatoms from sediment and oxygen isotope extraction from their siliceous valves: a new approach. In Terra Nostra, 2001/3. Schriften der Alfred-Wegener-Stiftung (6th workshop of the European lake drilling programme, POTSDAM); 187-191.

Schmidt, M., Botz, R., Stoffers, P., Anders, T. and Bohrmann, G. (1997). Oxygen isotopes in marine diatoms: A comparative study of analytical techniques and new results on the isotopic composition of recent marine diatoms. Geochimica et Cosmochimica Acta, 61, 2275-2280.

Schmidt, M., Botz, R., Rickert, D., Bohrmann, G., Hall, S.R. and Mann, S. (2001). Oxygen isotope of marine diatoms and relations to opal-A maturation. Geochimica et Cosmochimica Acta, 65, 201-211.

Schneider-Mor, A., Yam, R., Bianchi, C., Kunz-Pirrung, M., Gersonde, R. and Shemesh, A. (2005). Diatom stable isotopes, sea ice presence and sea surface temperature records of the past $640 \mathrm{ka}$ in the Atlantic sector of the Southern Ocean. Geophysical Research Letters, 32, L10704, doi:10.1029/2005GL022543.

Schneider-Mor, A., Yam, R., Bianchi, C., Kunz-Pirrung, M., Gersonde, R. and Shemesh, A. (2008). Nutrient regime at the siliceous belt of the Atlantic sector of the Southern Ocean during the past 660 Ka. Paleoceanography, 23, PA3217, doi:10.1029/2007PA001466. 
Shemesh, A., Mortlock, R.A., Smith R.J. and Froelich, P.N. (1988). Determination of Ge/Si in marine siliceous microfossils: separation, cleaning and dissolution of diatoms and radiolaria. Marine Chemistry, 25, 305-323

Shemesh, A., Charles, C.D. and Fairbanks R.G. (1992). Oxygen isotopes in biogenic silica: global changes in ocean temperature and isotopic composition. Science, 256, 1434-1436.

Shemesh, A., Macko, S.A., Charles, C.D. and Rau, G.H. (1993). Isotopic evidence from reduced productivity in the glacial Southern Ocean. Science, 262, 407- 410.

Shemesh, A., Burckle, L.H. and Hays, J.D. (1994). Meltwater input to the Southern Ocean during the Last Glacial Maximum. Science, 266, 1542-1544.

Shemesh, A., Burckle, L.H. and Hays, J.D. (1995). Late Pleistocene oxygen isotope records of biogenic silica from the Atlantic sector of the Southern Ocean. Paleoceanography, 10, 179-196.

Shemesh, A., Hodell, D., Crosta, C., Kanfoush, S., Charles, C. and Guilderson, T. (2002). Sequence of events during the last deglaciation in Southern Ocean sediments and Antarctic ice cores. Paleoceanography, 17, 1056. doi: 10.1029/2000PA000599.

Sigman, D. M. and Haug, G. H. (2003). The biological pump of the past. In Treatise on Geochemistry volume 6, ed H. Elderfield, Elsevier, Amsterdam.

Sigman, D. M., Altabet, M. A., Francois, R., McCorkle, D. C. and Gaillard, J. F. (1999). The isotopic composition of diatom-bound nitrogen in the Southern Ocean sediments. Paleoceanography, 14, 118134.

Singer, A.J. and Shemesh, A. (1995). Climatically linked carbon isotope variation during the past 430,000 years in Southern Ocean sediments. Paleoceanography, 10, 171-177.

Spadaro, P.A. (1983). Silicon isotope fractionation by the marine diatom Phaeodactylum tricornutum. Unpublished M. Sc. thesis, University of Chicago.

Spero, H.J. and Lea, D.W. (1993). Intraspecific stable isotope variability in the planktonic foraminifera Globigerinoides sacculifer: results from laboratory experiments. Marine Micropaleontolgy, 22, 221234.

Spero, H.J. and Lea, D.W. (1996). Experimental determination of stable isotope variability in Globigerina bulloides: implications for paleoceanographic reconstructions. Marine Micropaleontology, 28, 231-246.

Spero, H. J., Bijma, J., Lea, D.W. and Bemis, B. (1997). Effect of seawater carbonate chemistry on planktonic foraminiferal carbon and oxygen isotope values. Nature, 390, 497-500.

Street-Perrott, F.A., Barker, P.A., Leng, M.J., Sloane, H.J., Wooller, M.J., Ficken, K.J., Swain, D. L. (2008). Towards an understanding of late Quaternary variations in the continental biogeochemical cycle of silicon: mult-isotope and sediment-flux data for Lake Rutundu, Mt Kenya, East Africa, since 38 ka BP. Journal of Quaternary Science, 23, 375-387. 
Swann, G.E.A. and Leng, M.J. (2009). A review of diatom $\delta^{18} \mathrm{O}$ in palaeoceanography. Quaternary Science Reviews, 28, 384-398.

Swann, G.E.A., Maslin, M.A., Leng, M.J., Sloane, H.J. and Haug, G.H. (2006). Diatom $\delta^{18}$ O evidence for the development of the modern halocline system in the subarctic northwest Pacific at the onset of major Northern Hemisphere glaciation. Paleoceanography, 21, PA1009, doi: 10.1029/2005PA001147.

Swann, G.E.A., Leng, M.J., Sloane, H.J., Maslin, M.A. and Onodera, J. (2007). Diatom oxygen isotopes: evidence of a species effect in the sediment record. Geochemistry, Geophysics, Geosystems, 8, Q06012, doi:10.1029/2006GC001535.

Swann, G.E.A., Leng, M.J., Sloane, H.J. and Maslin, M.A. (2008). Isotope offsets in marine diatom $\delta^{18} \mathrm{O}$ over the last $200 \mathrm{ka}$. Journal of Quaternary Science, 23, 389-400.

Takeda, S. (1998). Influence of iron availability on nutrient consumption ratio of diatoms in oceanic waters. Nature, 393, 774-777.

Taylor, H.P. and Epstein, S. (1962). Relationships between 18O/16O ratios in coexisting minerals of igneous and metamorphic rocks, part I, Principles and experimental results. Bulletin of the Geological Society of America, 73, 461-480.

Thorliefson, J.T. (1984). A modified stepwise fluorination procedure for the oxygen isotopic analysis of hydrous silica. Unpublished M. Sc. thesis, Arizona State University.

Tyler, J.J., Leng, M.J. and Sloane, H.J. (2007). The effects of organic removal treatment on the integrity of $\delta^{18} \mathrm{O}$ measurements from biogenic silica. Journal of Paleolimnology, 37, 491-497.

van Bennekom, A.J. and Van der Gaast, S.J. (1976). Possible clay structures in frustules of living diatoms. Geochimica et Cosmochimica Acta, 40, 1-6.

van den Boorn, S.H.J.M, Vroon, P.Z., van Belle, C.C., van der Wagt, B., Schwieters, J. and van Bergen, M.J. (2006). Determination of silicon isotope ratios in silicate materials by high-resolution MC-ICP-MS using a sodium hydroxide sample digestion method. Journal of Analytical Atomic Spectrometry, 21, 734-742.

Varela, D.E., Pride, C. J. and Brzezinski, M. A. (2004). Biological fractionation of silicon isotopes in Southern Ocean surface waters. Global Biogeochemical Cycles, 18, GB1047, doi: $10.1029 / 2003$ GB002140.

Wefer, G. and Berger, W.H. (1991). Isotope paleontology: growth and composition of extant calcareous species. Marine Geology, 100, 207-248.

Wischmeyer, A.G., De La Rocha, C.L., Maier-Reimer, E. and Wolf-Gladrow, D.A. (2003). Control mechanisms for the oceanic distribution of silicon isotopes. Global Biogeochemical Cycles, 17, 1083, doi:10.1029/2002GB002022. 
$\mathrm{H}_{2} \mathrm{O}$

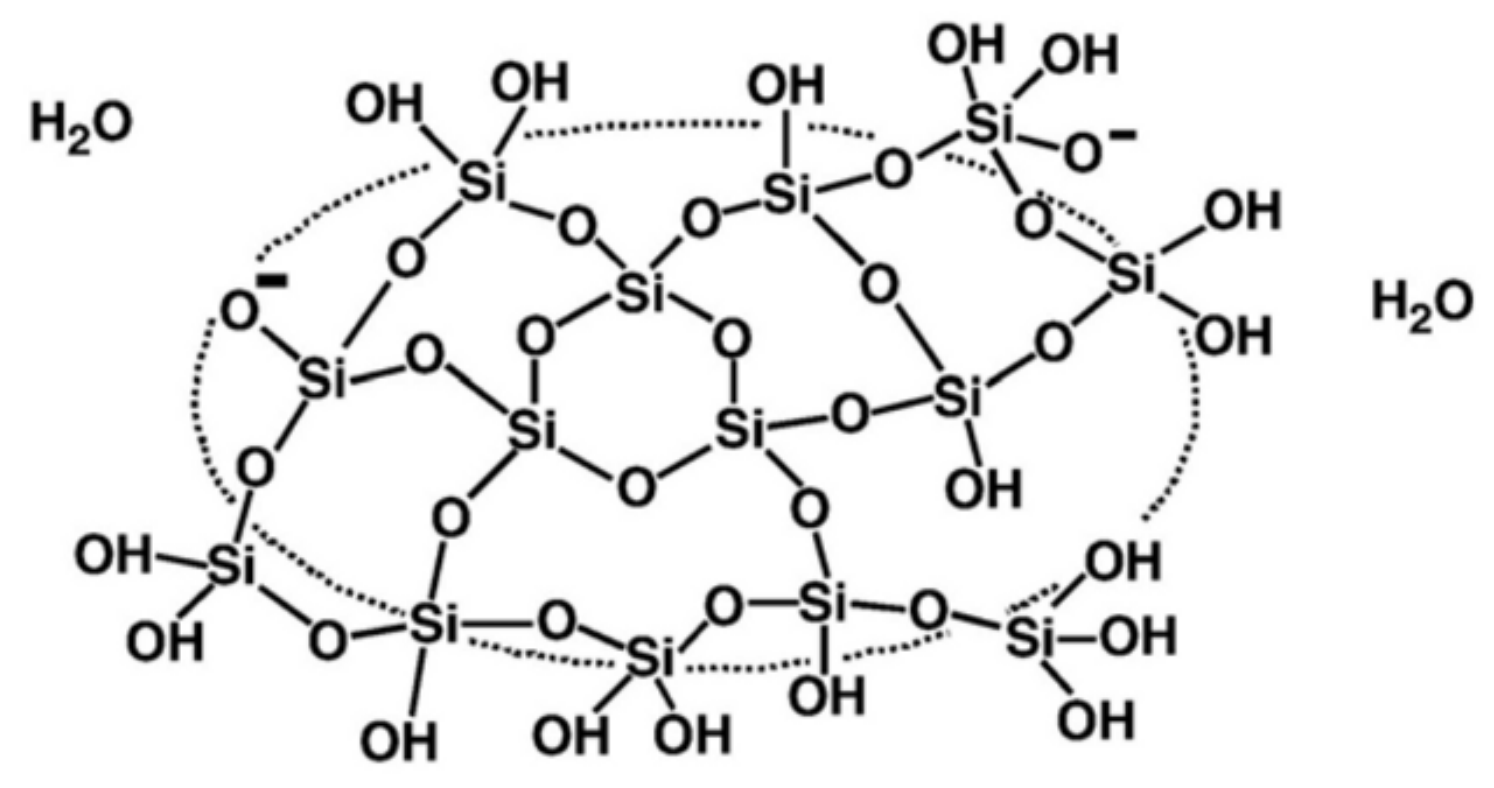

$\mathrm{H}_{2} \mathrm{O}$

$\mathrm{H}_{2} \mathrm{O}$

Figure 1 


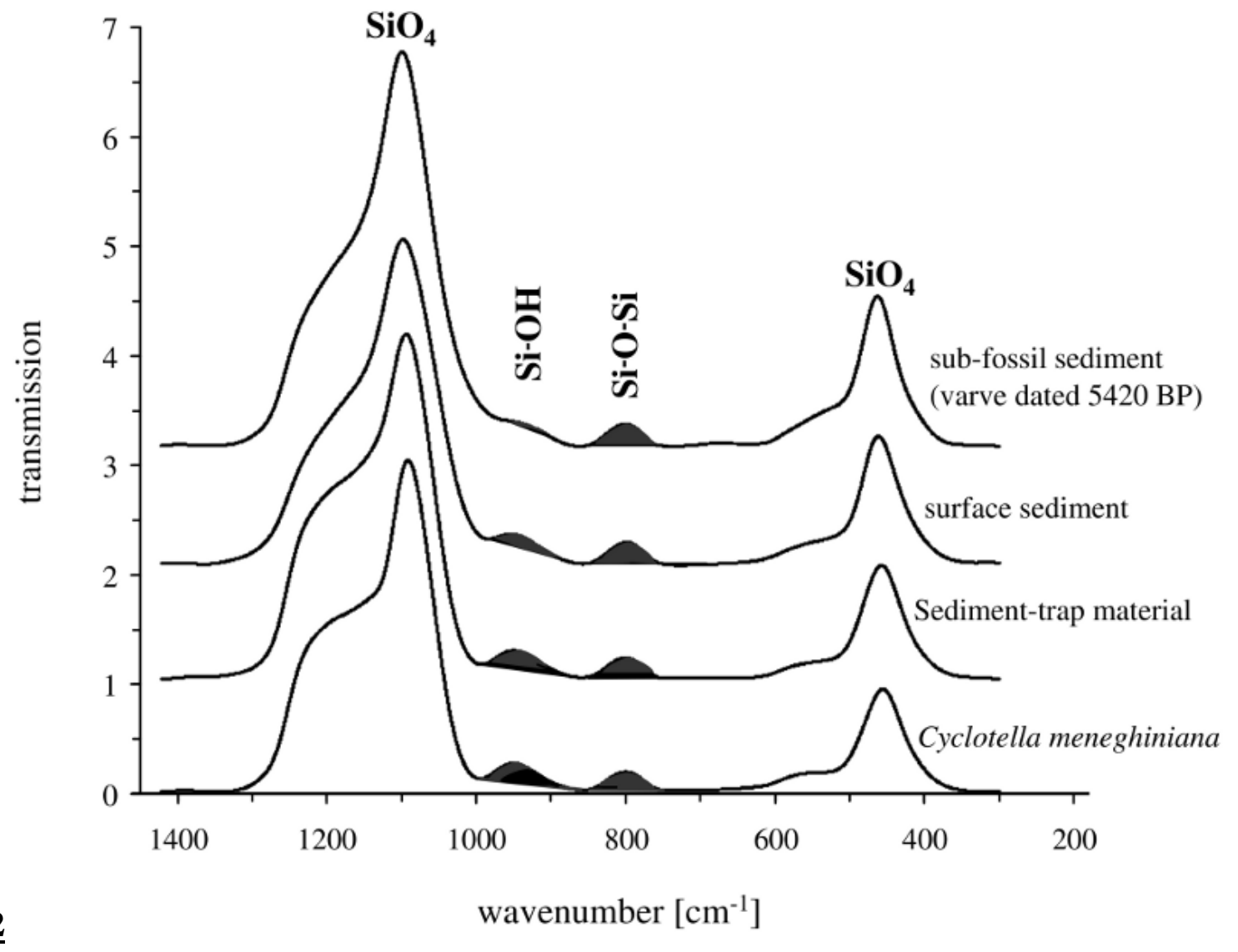

Figure 2 


\section{Figure 3}

a)

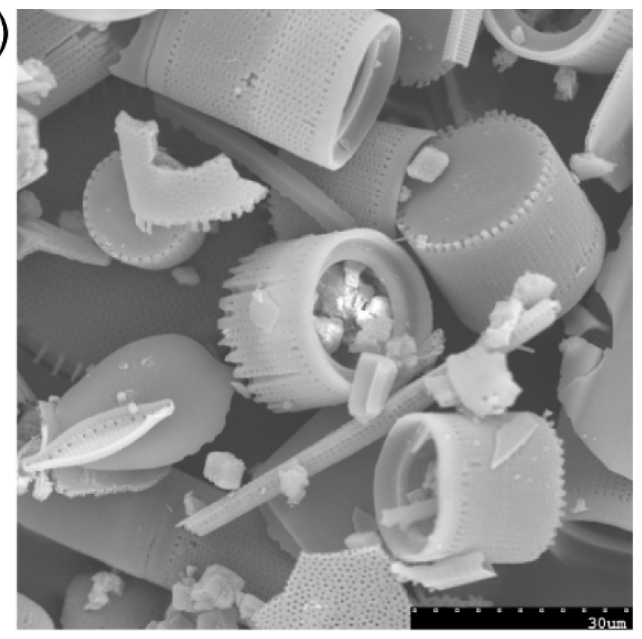

b)

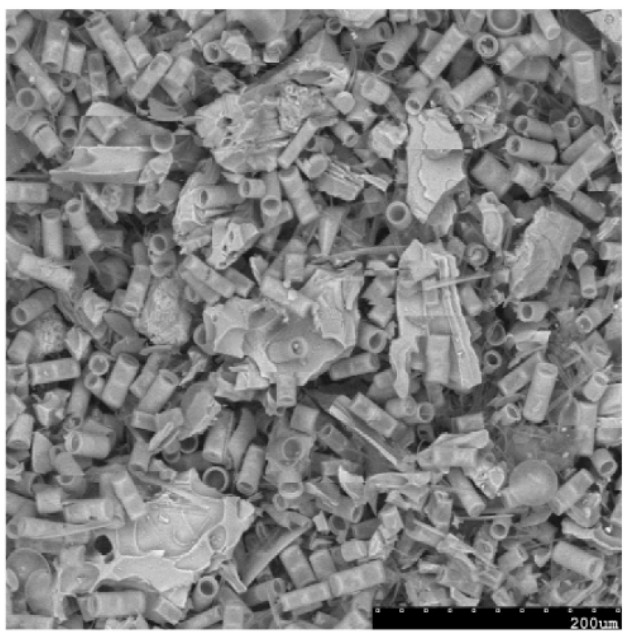

c)

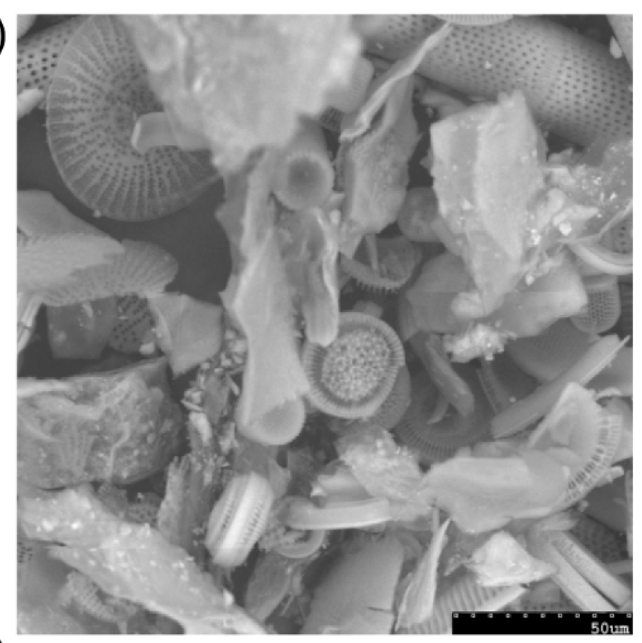

d)

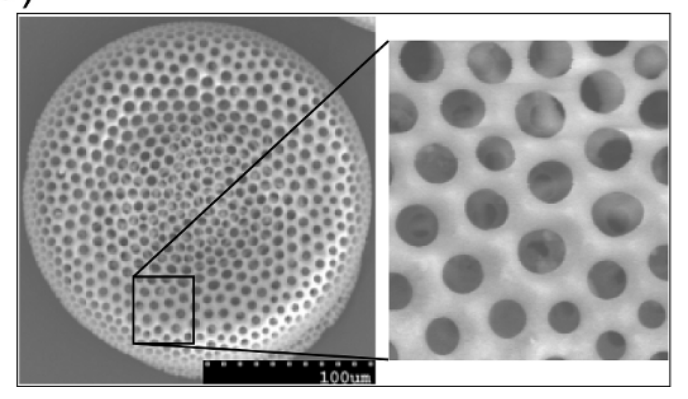

